\title{
Impact of Government and regulatory policy on hill country farming
}

\author{
A. CROFOOT \\ Castlepoint Station, RD 9, Masterton, New Zealand \\ anders@castlepoint.co.nz
}

\begin{abstract}
New Zealand has a long history of Government policy affecting agriculture. Some policy interventions, such as Producer Boards were long-lived, others like Land Development Encouragement Loans and the Supplementary Minimum Price scheme ramped up quickly and were then dismantled. Currently, the National Policy for Freshwater Management and the Emissions Trading Scheme are having mixed effects on hill country farmers. While regulation is often seen by farmers as a negative, environmental regulation has the potential to be used for market advantage. Farmers need to engage in policy and regulation development as they can help avoid unintended consequences. If they do not then they are ceding control of important aspects of their business to others. This paper explores some of the impacts of past and present policy on hill country farming from a farmer's perspective, and based on 9 years of regular involvement in development and implementation of policy at a local, regional and national level.
\end{abstract}

Keywords: policy, National Policy Statement for Freshwater Management, Emissions Trading Scheme, farmer engagement

\section{Key messages}

- Government policy may be successful but can have unintended consequences

- Farmer engagement in policy development can help achieve the goals and avoid unintended consequences

- Regulation although often seen as negative by famers can have positive economic benefits for them.

\section{Past Government policy affecting hill country farmers}

The New Zealand agricultural sector has over most of its history been subject to varying influences of Government policy. For example, the Producer Boards, established in the 1920s, were large scale and long running Government policies. While times have changed and those structures no longer exist, they have had varying degrees of success. The Dairy Board would widely be seen as a success and the current strength of the dairy industry would be testament to policies that have grown the industry, sometimes in response to industry direction, such as the Dairy Industry Restructuring Act to enable the creation of
Fonterra. The Wool Board would be at the other end of the spectrum where the wool industry has not prospered and with a lack of industry direction, such as voting for the removal of a wool commodity levy, policy intervention has withered away.

Other policies have been more narrowly focussed and while not being in place for a long, have had long-ranging effects. One such policy with an impact on hill country would be the Land Development Encouragement Loans (LDEL), introduced in 1978. LDELs were part of a suite of Government policies designed to increase exports, by increasing production including the Livestock Incentive Scheme (LIS) created in 1976 and Supplementary Minimum Price (SMP) scheme created in 1978.

These LDELs were concessional loans for the initial costs of development aimed at low producing hill country. The loans were for 15 years to a maximum of $\$ 250 /$ ha for vegetation clearance, re-sowing pastures, fertiliser, and fencing materials. The accumulated interest was written off and only half the principal was repayable. Improvements had to be maintained to the satisfaction of the Rural Bank (Sheppard 1993). The LDEL scheme was phased out by 1985.

\section{Outcomes of previous Government policies}

Overall, the schemes did create activity. From 1976 to 1981 New Zealand's total stock units increased by more than 9.1 million and gross capital investment in land doubled from 1978 to 1981. An analysis by Ministry of Agriculture and Fisheries in 1980 showed that for the 1980 financial year $40 \%$ of the development expenditure was sourced from LDEL and 17\% from LIS (Sheppard 1993). As an individual example, on Castlepoint Station in 1965 there were 1695 hectares of grazing land, of which only 684 ha was improved. The Station carried 12500 stock units. By 1985 with substantial help from LDEL scheme there was 2189 hectares of improved pastures and over 25000 stock units were carried. That is how the scheme was supposed to work. However, subsidising the cost of development, made it attractive for the landowner to convert marginal lands to pasture, which were unsustainable in the long run. Even by the mid 1980s some land was being cleared for the third time (Rudge 1986). Some of the country was also erosion prone, and the wholesale clearing that was encouraged has led to issues with sediment in waterways. So while the LDEL scheme had some 
success through increased production, there were some unintended consequences, such as erosion which now require new policy to address.

\section{Current Government policy affecting hill country farming approaches}

The New Zealand National Policy Statement for Freshwater Management 2014 (NPSFM) is a Government policy of a different sort. While Producer Boards and LDEL were national schemes that had direct impacts on farmers, the NPSFM is a directive to regional government to formulate new policy. Some of the key issues that will have strong impact on hill country farming include nutrient allocation, riparian fencing, and exclusion of stock from waterways.

Different regions are handling the required process of creating policy and setting limits as required in the NPFSM by quite different methods. For example, Otago Regional Council (ORC) has put in place effectsbased policies, where they leave it to the farmer as to how to best achieve the desired outcome with the resulting effect. For example, to protect water quality from the potentially damaging effects of cattle access. Under the Otago Regional Council Plan Change 6A, stock can have access to waterways as long as they do not damage the bank or bed or degrade the quality of the water by:

- causing slumping, pugging or erosion

- creating a visual change in the colour or clarity of the water.

In contrast, the Hawke's Bay Regional Council (HBRC) have taken a prescriptive approach and regulated the activity rather than the effect, to protect against the potential damaging aspects of cattle access. Under the Tukituki River Catchment Plan Change 6, all stock (except sheep) must be excluded from waterways.

There are pros and cons to each approach. The effectsbased ORC approach provides flexibility to achieve the desired outcomes, however, it potentially leaves uncertainty in the minds of farmers as to what they need to do to comply. The prescriptive HBRC approach provides certainty as to what is required, but takes away the flexibility of achieving the outcome by other methods. For example, to keep cattle out of waterways an alternate more convenient source of water could be supplied, that could keep cattle off stream banks, but does not strictly exclude them. In the worst case, blanket policy across a region to deal with what may be hotspot issues, can incur cost for no benefit.

Riparian planting is another policy which can go hand in hand with stock exclusion, but can have unintended negative consequences. Shading streams with vegetation can certainly improve the conditions for the stream biota, however, if there is stock exclusion and no management the stream banks can become havens for weed species. Close-spaced riparian plantings can also limit recreational access along waterways. A wide buffer strip can provide maximum attenuation of overland flows of sediment and nutrients, but it may be coming at the cost of the loss of highly productive land. In hill country flatter ground is especially valuable. In storm events when large scale erosion takes place, there may be so much overland flow of water that riparian plantings can not keep all sediment and nutrients out of the waterway (Barling \& Moore 1994). Water quality is affected by land use across the entire catchment. Sediment and nutrient loss are not limited to the stream banks. So practices to reduce erosion and runoff across the whole catchment will be required rather than just trying to rely on riparian restoration (Collins 2011).

\section{Approaches to nutrient leaching from farms}

Nutrient allocation, the process of defining numeric limits for nutrient leaching from the land to protect water quality is an area that will potentially have great impact on hill country farmers. A variety of policy approaches have been used in New Zealand in recent years including grandparenting, land allocation and natural capital.

Grandparenting has been used to address nitrogen (N) enrichment in Lake Taupo. Variation 5 to the Environment Waikato Regional Plan has allowed leaching levels based on the historical levels for individual farms in the sensitive catchments around Lake Taupo.

In Otago, Plan Change 6A takes a land allocation approach and all land regardless of use is given an allocation of N/ha/year in three bands: $15 \mathrm{~kg} / \mathrm{ha} /$ year for large lake catchments, $20 \mathrm{~kg} / \mathrm{ha} /$ year in sensitive aquifers and $30 \mathrm{~kg} / \mathrm{ha} /$ year elsewhere. Horizons Regional Council in their "One Plan" for ManawatuWanganui, has taken a natural capital approach. This assigns allowed leaching values to the various Land Use Capability (LUC) units, with the more productive LUC units allocated higher leaching rates (Holgate 2015).

Each of these approaches has attractions. Grandparenting means the farmer will most likely be able to continue with existing land use. Land allocation is simple and does not favour any particular land use. Natural capital allows productive lands to leach more than less productive land, which matches with the OVERSEER ${ }^{\circledR}$ modelling that high production land use tends to leach more than low production land use.

Hill country farmers need to pay close attention to any system that caps their existing low $\mathrm{N}$ leaching levels which may prevent them for intensifying their operations which grandparenting is most likely to do. 


\section{Environment policy economic positives and Government policy}

Climate change policy, in particular the Emissions Trading Scheme (ETS), has had an impact on New Zealand hill country farmers since forestry entered the ETS in 2008. It has been beneficial to those in the forestry industry, including hill country farmers, who have participated. Selling New Zealand credits at \$20 and replacing them with other credits at a much lower cost has been lucrative. However, tinkering and changing policy has not been helpful: changes in eligibility criteria have shifted, processes can be difficult for the uninitiated, precipitous rule change have left some ETS participants out of pocket. This means that the tree planting that was supposed to be encouraged has not eventuated (Crofoot 2009). The policy has potential to achieve its goals, but a global crash in the price of carbon and erratic policy settings have conspired against it.

Farmers often view government policy and regulations in a negative light. It limits their flexibility and adds costs. However, policy can enable farmers as it has been in the past with the LDEL, LIS and SMP schemes. More recently some have benefited from the ETS. In the future, environmental regulation could be an opportunity to showcase New Zealand farmers' environmental performance. Regulation gives a Government guarantee to the market about measured and verified credentials. There could be potential for this to be used to add value for the New Zealand farmer by the processors and marketers (Holgate 2015) much as the National Bovine Tuberculosis Pest Management Strategy currently does for providing market access (MPI 2010).

\section{Farmer involvement in policy setting}

It is important for farmers to be involved with the development of policy and regulation. This can happen through collaborative processes, which are encouraged in the NPSFM implementation guide. While the processes can be challenging they can work (Powell 2012). Collaboration allows the farmer to bring practical knowledge and experience to the process, however, it can consume a great deal of time. The traditional routes of submissions and hearings with their formality and semi-judicial process can be quite intimidating for farmers. A semi-judicial process can limit the scope of discussion, which saves time, but exclude options that were not introduced early in the process.

Policy can often have unintended consequences. LDELs were not intended to create erosion problems, but they subsidised the conversion of steep erosion prone hill country, under scrub and forest cover to pastoral farming despite the known erosion problems of this land (Basher 2013). Farmers are good at pointing out unintended consequences of new policy or regulations, not only due to their experience on the ground with the issues trying to be addressed, but they can also say how they will react. If farmers have a good understanding of what the issues are then they may be able to suggest alternative solutions, such as places where good management practice may be sufficient and more flexible to provide a solution. If farmers are not involved from the beginning of the policy process then they are ceding control of some important aspects of their business to others.

\section{REFERENCES}

Barling, R.D.; Moore, I.D. 1994. Role of buffer strips in management of waterway pollution: a review. Environmental Management 18: 543-558.

Basher, L.R. 2013. Erosion processes and their control in New Zealand. pp. 363-374. In: Ecosystem services in New Zealand. Ed. Dymond. J. Manaaki Whenua Press. Lincoln, New Zealand.

Collins, K. E. 2011. Evaluating the effectiveness of riparian plantings on water quality: a case study of lowland streams in the Lake Ellesmere catchment. Masters thesis. Lincoln University. 109 pp.

Crofoot, A.N. 2009. Carbon credits - reliable cashflow? Proceedings of the New Zealand Grassland Association 71: 85-88.

Dairy Industry Restructuring Act 2001. Accessed: December 2015. http://www.legislation.govt.nz/act/ public/2001/0051/latest/whole.html\#DLM106751

Hawkes Bay Regional Council. Plan Change 6 to Hawke's Bay Regional Resource Management Plan. Accessed: December 2015. http://www.hbrc.govt. nz/HBRC-Documents/HBRC Document Library/ Regional Plan Change 6 - Tukituki River Catchment (Operative 1 October 2015) excl. planning maps.pdf

Holgate, B. 2015. Environmental opportunities making regulation work for New Zealand sheep and beef farmers. Special edition 2015, Rabobank Agribusiness Report. 24 pp.

Horizons Regional Council. One Plan, the Consolidated Regional Policy Statement, Regional Plan and Regional Coastal Plat for the Manawatu-Wanganui Region. Accessed: December 2015. http://www. horizons.govt.nz/assets/publications/about-uspublications/one-plan/Horizons-Regional-CouncilOne-Plan-Title.pdf

Ministry for Primary Industries. 2010. Review of the national bovine tuberculosis pest management strategy, regulatory impact statement. Accessed: December 2015. http://mpi.govt.nz/document-vault/3941

Ministry for the Environment. National Policy Statement for Freshwater Management 2014. Accessed: December 2015. http://www.mfe.govt.nz/ sites/default/files/media/Fresh water/nps-freshwatermanagement-jul-14.pdf 
Otago Regional Council. Plan change 6A. Accessed: December 2015. http:/Www.orc.govt.nz/Documents/ Publications/Regional/Water/Plan Change 6A/Water Quality Rules/Otago Water Plan Change 6A.pdf

Powell, B. 2012. Lessons learnt from a collaborative approach to Nutrient Management in Taharu catchment. In: Advanced nutrient management: gains from the past - goals for the future. Occasional Report No. 25. Fertilizer and Lime Research Centre, Massey University. 5 pp.
Rudge, M.R. 1986. Presidential address: science, land management, and accountability. New Zealand Journal of Ecology 9: 1-10.

Sheppard, R. 1993. New Zealand agricultural policy change: some effects. Agribusiness and Economics Research Unit Discussion Paper 135, Lincoln University. 33 pp. 